\title{
ANALYSIS OF CORPORATE GOVERNANCE DISCLOSURE: A STUDY ON BRAZILIAN COMPANIES
}

\author{
ANÁLISE DA DIVULGAÇÃO DE GOVERNANÇA \\ CORPORATIVA: UM ESTUDO SOBRE EMPRESAS \\ BRASILEIRAS
}

\author{
ANÁLISIS DE LA DIVULGACIÓN DE GOBIERNO \\ CORPORATIVO: UN ESTUDIO DE LAS EMPRESAS \\ BRASILEÑAS
}

\author{
Marcelle Colares Oliveira \\ Doutora em Controladoria e Contabilidade pela \\ Universidade de São Paulo, Brasil / Professora \\ associada da Universidade Federal do Ceará (UFC), \\ Brasil / Ex-Vice-Coordenadora do Mestrado \\ Profissional em Administração e Controladoria da UFC \\ marcellecolares@uol.com.br \\ Domenico Ceglia \\ Mestre em Administração e Controladoria pela \\ Universidade Federal do Ceará, Brasil / Doutorando em \\ Administração de Empresas da Universidade Federal do \\ Rio Grande do Sul, Brasil \\ ceglia@gmail.com \\ Lais Silva Lima \\ Graduada em Ciências Contábeis pela Universidade \\ Federal do Ceará, Brasil \\ limlais@gmail.com \\ Vera Maria Rodrigues Ponte \\ Doutora em Ciências Contábeis pela Universidade de \\ São Paulo, Brasil / Professora associada do Programa de \\ Pós-graduação em Administração, da Universidade \\ Federal do Ceará, Brasil \\ limlais@gmail.com
}

Contextus

ISSNe 2178-9258

Organização: Comitê Científico Interinstitucional Editor Científico: Carlos Adriano Santos Gomes Avaliação: double blind review pelo SEER/OJS Edição de texto e de layout: Carlos Daniel Andrade Recebido em 14/03/2017 Aceito em 21/06/2017 $2^{a}$ versão aceita em 29/07/2017

\begin{abstract}
This study aims to compare Brazilian legislation to United Nations' international recommendation with respect to the influence of each on the disclosure level of Brazilian companies' CG practices. The theoretical approach is institutional theory. It is an exploratory study because CG disclosure is an insufficiently studied phenomenon in the light of institutional theory. The research amounts to a qualitative but also a quantitative one since its procedures encompass content analysis techniques to collect data and statistical tools to analyze them. Data were collected from all the companies belonging to IBOV Index, an indicator of the average quotations of Brazilian stock market's most traded, representative shares. It was concluded that coercive forces exert more influence on the disclosure of corporate governance by the Brazilian companies studied, which means legally required indicators were more disclosed than those simply recommended by United Nations.
\end{abstract}


Keywords: Corporate Governance. Disclosure. Brazilian Companies. Institutional Theory. United Nations.

\section{RESUMO}

O objetivo deste estudo é comparar a legislação nacional e a recomendação internacional das Nações Unidas quanto à influência de cada uma sobre o nível de divulgação das práticas de governança corporativa por parte de empresas brasileiras. A abordagem é a teoria institucional. Trata-se de estudo exploratório, pois a divulgação de governança corporativa é fenômeno pouco estudado à luz da teoria institucional. Os procedimentos são qualitativos, mas também quantitativos, na medida em que usa técnicas de análise de conteúdo para coletar dados, bem como ferramentas estatísticas para analisá-los. Os dados foram coletados de todas as empresas pertencentes ao índice IBOV, indicador das cotações médias das ações mais negociadas e mais representativas do mercado de ações brasileiro. Concluiu-se que as pressões coercitivas exercem mais influência sobre a divulgação de governança corporativa por parte das empresas brasileiras estudadas, o que significa que indicadores exigidos por lei foram mais divulgados que aqueles simplesmente recomendados pelas Nações Unidas.

Palavras-Chave: Governança corporativa. Divulgação. Empresas brasileiras. Teoria institucional. Nações Unidas.

\section{RESUMEN}

El objetivo de este estudio es comparar la legislación brasileña con la recomendación internacional de las Naciones Unidas en cuanto a la influencia de cada una sobre el nivel de divulgación de las prácticas de gobierno corporativo de las empresas brasileñas. El enfoque es la teoría institucional. Se trata de un estudio exploratorio, ya que la divulgación del gobierno corporativo es un fenómeno poco estudiado a la luz de la teoría institucional. Los procedimientos tienen naturaleza cualitativa, pero también cuantitativa, ya que incluyen la técnica de análisis de contenido para recopilar datos y herramientas estadísticas para analizarlos. Se recogieron datos de todas las empresas pertenecientes al índice IBOV, un indicador de los precios medios de las acciones más negociadas y más representativas de la bolsa brasileña. Se concluyó que las presiones coercitivas ejercen sobre las empresas brasileñas estudiadas una mayor influencia en cuanto a la divulgación de gobierno corporativo, lo que significa que los indicadores obligatorios han sido más divulgados que los simplemente recomendados por las Naciones Unidas.

Palabras clave: Gobierno corporativo. Divulgación. Empresas brasileñas. Teoría institucional. Naciones Unidas.

\section{INTRODUCTION}

Corporative scandals due to financial frauds in the 2000s stressed the conflict of interest that emerged from stockholders' low power of control and agents' unethical behavior. From this conflict of interest, an agency cost arose insofar as both sides sought to maximize their own interests (JENSEN; MECKLING, 1976). In the real world, agency cost is unavoidable because a firm is a nexus of contracts between agents involved (COASE, 1937).

After the corporative scandals in the 2000s, certain institutions undertook 
initiatives seeking to strengthen corporate governance (CG). For instance, in 2004 the Organization for Economic Cooperation and Development (OECD) reviewed its OECD Principles Of Corporate Governance (OECD, 2004), originally launched in 1999. In 2002, the United States (US) approved the Sarbanes-Oxley Act 2002, a federal law that regulates CG practices (UNITED STATES, 2002). In 2006, the United Nations Conference on Trade and Development (UNCTAD) offered its own contribution as well: Its Intergovernmental Working Group of Experts on International Standards of Accounting and Reporting (ISAR) launched the Guidance on Good Practices in Corporate Governance Disclosure (UNCTAD, 2006), a code of best practices for CG and its disclosure in annual reportings. It has been used as a reference for a number of United Nations studies on CG disclosure (OLIVEIRA, 2013; UNCTAD, 2010, 2011a, 2011b).

In the academic context, CG disclosure was investigated in the light of UN recommendations, for example, by Samaha, Dahawy, Hussainey and Stapleton (2012) and Vicente, Borba, Alves and Scharf (2007), but it is still not deeply studied under theoretical approaches. On the other hand, a few studies have begun to use institutional theory to try to explain the influence of institutional pressures on corporate practices such as disclosure. Also this study intends to use that theory as its underpinning. Institutions, according to Scott (1995), are governments, professional organizations, public interest groups and the general public. Each party exerts some pressure on companies: government uses coercive forces, i.e. rules, laws and sanctions; professional organizations use normative forces, i.e. social norms, social obligations, accreditations and certifications; and public interest groups use mimetic forces, i.e. cultural norms composed of common beliefs.

Since there are not many studies focusing on institutional theory or on the effectiveness of practice disclosure as required by both national rules and international recommendations, this theme will be investigated here. Accordingly, the following research question will be addressed: What kind of institutional forces has greater influence on the CG disclosure of Brazilian companies: coercive or normative?

The study's purpose is to compare national legislation to UNCTAD's international recommendation with respect to the influence of each on the disclosure level of Brazilian companies' CG practices. It is an exploratory study 
because the $\mathrm{CG}$ disclosure is still a phenomenon insufficiently studied in light of institutional theory. The research is mostly based on a review of documents and literature but, generally speaking, it involves qualitative and quantitative procedures because it also uses a content analysis method to collect data and statistical tools to analyze them. It focuses on Brazilian companies belonging to BM\&FBOVESPA index (IBOV). Thus, the results cannot be generalized but they can show evidence of how disclosure of corporate governance information works in Brazil.

The research goes forward in the field of $\mathrm{CG}$ disclosure since it investigates more deeply international normative pressure for disclosure in a country whose laws, rules and legal norms in this respect are robust and primarily base on codes. Moreover, institutional theory helps to understand the differences between coercive and normative forces on CG disclosure. No similar studies have been published in Brazil to date.

The paper is orchestrated as following: in section two, it provides an overview of pillars of institutional theory, discusses UNCTAD's recommendations and studies related to the theme, as well as presents recent developments in rules and regulations about $\mathrm{CG}$ in Brazil. In section three, the methodological concepts and tools used to answer the research question and the Wilcoxon signed-rank test are presented. In section four, the results are shown and a discussion is undertaken to proceed to the conclusion.

\section{THEORETICAL UNDERPINNING}

\subsection{Coercive and normative pressure on CG disclosure}

A reduction of asymmetry reduces the cost of capital, as argued Diamond and Verrecchia (1991), which entails that companies are interested in reducing asymmetry by means of mandatory and voluntary disclosure. In several countries, companies need to justify their noncompliance with their country's code of good governance. This policy adopted by most stock exchanges encourages firm compliance (AGUILERA; CUERVOCAZURRA, 2004).

Institutional pressure can be exerted either by laws, rules and sanctions-issued by the government, which have coercive nature-or by norms, issued by professional associations, supranational entities, etc., which have rationalized concepts of organizational work. These norms are fulfilled somewhat voluntarily. For example, if one company wants to 
obtain a specific certification, it must fulfill some requirements about a norm issued by a certification board. Since such requirements have no coercive nature, the company is not obliged to follow them if it has no interest in obtaining the specific certificate.

In Japan, for instance, law follows a shareholder sovereignty model in letting few protections for minority shareholders and weak information disclosure requirements to oversee the problems in corporate control. By contrast, in the US, where the liberal market model is adopted, corporate disclosure is higher (AGUILERA; JACKSON，2003). It is important to highlight in the US there are rules that obligate the disclosure of corporate governance information-for example, in the 20-F document-and sanctions imposed by rules for noncompliance. Therefore, according to the model of capital market, corporate disclosure could be influenced by coercive or normative forces.

In 2009, among instructions issued by Brazilian Securities and Exchange Commission (CVM), ICVM \#480/09 mandated the disclosure of some indicators on corporate governance, such as company ownership structure, among others. According to that instruction, if those indicators were omitted in the Reference
Form (a document required by CVM for all companies that want to trade their stocks), then the companies would be fined and penalties would be allocated (BRASIL, 2009). Stock Exchange in Hong Kong encourages a culture of voluntary disclosure to avoid over-regulation, because it believes the quality of a company's disclosure to be reflected on its stock price (HO; WONG, 2001). In their study, previous authors found that, on the one hand, higher proportion of family members in the board does not influence voluntary disclosure; on the other hand, an audit committee does contribute a higher level. The presence of the audit committee suggests normative influence and pressures firms to follow some disclosure standards.

In Singapore Stock Exchange listed firms, Eng and Mak (2003) found that lower managerial ownership and significant governmental ownership are associated with increased voluntary disclosure so as to reduce moral hazards and agency problems. Under this light, an increase in outside directors reduces voluntary disclosure. Against the belief of the Stock Exchange in Hong Kong, according to Gilson (2000, p. 7), "disclosure is not effective unless investors can rely on the credibility of the information disclosed. The most straightforward way to assure that 
credibility is to mandate disclosure by law, and impose significant penalties on those who publish inaccurate information."

In Australia, the companies listed in Australian Stock Exchange voluntarily disclose their information about corporate governance to reduce information asymmetry in capital markets for share issues before these are negotiated (COLLETT; HRASKY, 2005). However, this reduction of informational asymmetry is also affected by a certain standardization of information, which reinforces the important role of the standards issued by professional associations and international organizations.

In Kenya, the presence of an audit committee is positively related to the level of voluntary disclosure, but the proportion of non-executive directors in the board stands out as a negative aspect. In contrast, board leadership structure has no significant influence on the level of voluntary disclosure by companies (BARAKO; HANCOCK; IZAN, 2006). Cheng and Courtenay (2006) analyzed information disclosed by 104 companies in Singapore and they realized firms with a higher proportion of independent directors in the board were related to higher levels of voluntary disclosure, but board size and CEO duality are not associated with voluntary disclosure.
Samaha et al. (SAMAHA et al., 2012), in a study on CG among Egyptian companies, found a low level of disclosure, except for mandatory items. Indeed, there are 41 items required by Egyptian Stock Exchange (EGX) among 53 recommended by UNCTAD. Anyway, the authors noted the disclosure level is lower for the items required by EGX than for Egyptian Accounting Standards. This could be due to the ineffectiveness and inadequacy of the regulatory framework in Egypt and other social problems (SAMAHA et al., 2012).

Among Brazilian companies listed in the New Market segment of BM\&FBovespa Stock Exchange (previously called Bovespa) in 2005 and 2006, a study conducted by Vicente et al. (2007) found the disclosure of corporate governance information not to completely comply with the UNCTAD recommendations. In particular, only two companies disclosed 11 and 13 items respectively among 18 elected from those 53 recommended by UNCTAD (2006).

While searching for evidence for the effectiveness of its Guidance on Good Practices in Corporate Governance Disclosure, the UN investigated in 2007 whether $\mathrm{CG}$ practices recommended by it were required by codes of good practices in capital markets of 25 developing 
countries and economies in transition. It found most of the codes of these countries to require the adoption and disclosure of more than half of the items from the guide (UNCTAD, 2007).

In 2008, the UN investigated the disclosure of CG practices recommended in its guide by one hundred companies from emerging markets, comprising the top ten of each of the following countries: South Africa, Brazil, China, South Korea, India, Israel, Indonesia, Malaysia, Mexico and Russia. It concluded that on average the firms in the sample disclosed more than half of the recommended indicators, although in that year the adoption and disclosure of these practices were neither required nor recommended by national institutions. Furthermore, practices relating to audit were less widely disclosed (UNCTAD, 2008).

In 2009, the UN turned to the largest companies from 12 emerging markets: Argentina, Chile, Colombia, Republic of Slovakia, Egypt, Hungary, Morocco, Peru, Philippines, Poland, Thailand and Turkey. Such companies were found to have disclosed about $70 \%$ of the items recommended by the UN, even when not required by law. Practices related to corporate social responsibility were less reported (UNCTAD, 2009).

In 2011, the UN released a research on 25 countries: 22 emerging ones as well as Japan, the United Kingdom (UK) and the US. The study compared the norms requiring the disclosure of practices of corporate governance recommended by $\mathrm{UN}$ in those countries and examined the disclosure by 188 companies from emerging markets plus 10 from Japan, 10 from the UK and 10 from the US. In short, the study concluded there were improvements but much remained to be done for the adoption of best practices of corporate governance and disclosure in most of the developing countries. It admitted national, professional and international institutions, such as government, auditing firms, OECD, the International Corporate Governance Network (ICGN) to have a major influence in spreading these practices by adopting and recommending widely recognized standards (UNCTAD, 2011b).

Oliveira (2013) published a case study on leading Brazilian companies using the benchmark of good practices in CG disclosure developed by UNCTAD. The findings show that, on average, firms listed in the IBOV disclose more than three quarters of the items from the UNCTAD's guide. The study concludes, on the one hand, that the firms in the sample primarily disclosed items made mandatory by regulations issued by government agencies. On the other hand, several firms 
voluntarily disclosed non-mandatory items recommended by UNCTAD and by the Brazilian Institute of Corporate Governance (IBGC). This result reinforces the importance of studying the institutional influence of coercive and normative pressure on CG disclosure.

\subsection{Overview of developments in CG disclosure in Brazil}

In Brazil, regulations on $\mathrm{CG}$ practices and disclosure stem from two different sources: a) governmental bodies and institutions, such as legislative bodies, CVM and the Brazilian Central Bank (BACEN); and b) private institutions, such as BM\&FBovespa, corporate governance institutes and similar associations, investors and company groups, professional associations, etc. The mechanisms and practices determined by government bodies and agencies (public sector) can be classified as mandatory, whereas those outlined by private institutions (private sector) can be either mandatory or voluntary.

In addition, while adherence to a corporate governance practice may be mandatory, its disclosure may not. In other words, disclosure may be mandatory in general or for specific items, or it may not be required at all. Thus, there is a natural tendency among Brazilian firms to disclose
CG practices adopted by them only when it is mandatory, even if the adoption of the corporate governance practice is determined by law. This behavior is influenced by the fact the Brazilian legal system is based primarily on law codes. However, this scenario is changing due to pressures from external entities encouraging the adoption of isomorphism.

The most important steps towards implementing corporate governance in Brazil were taken in the late 1990s and in the beginning of the 21 st century in form of a set of legal and institutional measures. However, this study focuses on developments that have occurred since 2007. In the past few years, not only relevant changes have been made by mandatory mechanisms but also disclosure regulations have been issued by public institutions, consolidating corporate governance in Brazil. Essential corporate governance requirements are specified in federal laws and in regulations issued by CVM. The most important legal development was the issuance of two laws: $\# 11.638 / 2007$ and \#11.941/2009. These introduced changes in accounting rules focused on the convergence of Brazilian accounting practices with internationally accepted accounting standards (IAS/IFRS). However, the disclosure of these new practices is not always mandatory. 
It is important to highlight the significant improvement in $\mathrm{CG}$ disclosure quality enabled by the issuance of CVM Instruction \#480/09, which made the publication of the Reference Form (RF) mandatory (the Brazilian RF was inspired by the American 20-F). However, as explained above, disclosure of mandatory practices may be general or itemized (covering specific items only, rather than a whole set of practices).

It is also worth mentioning that in 2009 the IBGC published the $4^{\text {th }}$ edition of its code of best practice of corporate governance. The compliance with it is voluntary, since it belongs to normative initiatives. From the 52 indicators recommended by UNCTAD, 50 are recommended by IBGC as well. Finally, it is important to mention that BM\&FBovespa's rules of the special listing segments (New Market, Level 1 and Level 2) has guidelines on $\mathrm{CG}$ practices and disclosure but not all of them are mandatory. Considering that Brazil's legal system is based primarily on law codes and in view of the recent issue of legal regulations related to $\mathrm{CG}$ practices and disclosure, we present the hypothesis below:

H1: The disclosure of corporate governance information by Brazilian companies is more influenced by coercive pressure from laws, rules and sanctions than by normative pressure from recommendations issued by international organizations.

\section{METHODOLOGY}

Data were collected from all the companies belonging to IBOV as of March 2013. Back then, there were 64 companies in the index, which refers to the average quotations of Brazilian stock market's most traded, representative shares. The firms belong to differentiated segments ("New Market" and "Differentiated Practices of Corporate Governance" Level 1 and Level 2) and to the general BM\&FBovespa listing. All firms investigated are subject to Brazilian corporate law and CVM regulations (instructions and decisions). These firms represent the top Brazilian ones covering 27 economic sectors according to the BM\&FBovespa classification.

To analyze the disclosure of governance indicators, a framework of indicators recommended by UNCTAD was used as a benchmark (see Table 1). It is composed by 52 items (representing the study's subcategories of analysis) and classified into 5 groups (representing the study's categories of analysis): Ownership structure and exercise of control rights; 
Financial transparency; Auditing; Board and management structure and process; and Corporate responsibility and compliance. Brazilian companies listed in BM\&FBOVESPA are required by law and by $\mathrm{CVM}$ instructions and deliberations to disclose 31 indicators from those 52 recommended by UNCTAD. In Table 1 , the indicators that are required by national rules are marked with "1".

Table 1 - Indicators required by national rules vs recommended by UNCTAD

\begin{tabular}{|c|c|c|c|}
\hline N. & Subcategory & $\begin{array}{l}\text { Required } \\
\text { in Brazil }\end{array}$ & $\begin{array}{l}\text { Recommended } \\
\text { by UNCTAD }\end{array}$ \\
\hline \multicolumn{2}{|r|}{ Ownership structure and exercise of control rights (category) } & 8 & 9 \\
\hline 1 & Ownership structure & 1 & 1 \\
\hline 2 & Process for holding annual general meetings & 1 & 1 \\
\hline 3 & Changes in shareholdings & 1 & 1 \\
\hline 4 & Control structure & 1 & 1 \\
\hline 5 & Control and corresponding equity stake & 1 & 1 \\
\hline 6 & Availability and accessibility of meeting agenda & 1 & 1 \\
\hline 7 & Control rights & 1 & 1 \\
\hline 8 & $\begin{array}{l}\text { Rules and procedures governing the acquisition of corporate control in } \\
\text { capital markets. }\end{array}$ & 1 & 1 \\
\hline 9 & Anti-Takeover measures & 0 & 1 \\
\hline \multicolumn{2}{|c|}{ Financial transparency (category) } & 8 & 8 \\
\hline 10 & Financial and operating results & 1 & 1 \\
\hline 11 & Critical accounting estimates & 1 & 1 \\
\hline 12 & Nature, type and elements of related-party transactions & 1 & 1 \\
\hline 13 & Company objectives & 1 & 1 \\
\hline 14 & Impact of alternative accounting decisions & 1 & 1 \\
\hline 15 & $\begin{array}{l}\text { The decision-making process for approving transactions with related } \\
\text { parties }\end{array}$ & 1 & 1 \\
\hline 16 & Rules and procedure governing extraordinary transactions & 1 & 1 \\
\hline 17 & Board's responsibilities regarding financial communications & 1 & 1 \\
\hline \multicolumn{2}{|c|}{ Auditing (category) } & 4 & 9 \\
\hline 18 & Process for interaction with internal auditors & 0 & 1 \\
\hline 19 & Process for interaction with external auditors & 0 & 1 \\
\hline 20 & Process for appointment of external auditors & 0 & 1 \\
\hline 21 & $\begin{array}{l}\text { Process for appointment of internal auditors / Scope of work and } \\
\text { responsibilities }\end{array}$ & 0 & 1 \\
\hline 22 & Board confidence in independence and integrity of external auditors & 0 & 1 \\
\hline 23 & Internal control systems & 1 & 1 \\
\hline 24 & Duration of current auditors & 1 & 1 \\
\hline 25 & Rotation of audit partners & 1 & 1 \\
\hline 26 & Auditors' involvement in non-audit work and the fees paid to the auditors & 1 & 1 \\
\hline \multicolumn{2}{|r|}{ Corporate responsibility and compliance (category) } & 1 & 7 \\
\hline 27 & $\begin{array}{l}\text { Policy and performance in connection with environmental and social } \\
\text { responsibility }\end{array}$ & 0 & 1 \\
\hline 28 & $\begin{array}{l}\text { Impact of environmental and social responsibility policies on the firm's } \\
\text { sustainability }\end{array}$ & 0 & 1 \\
\hline 29 & A code of ethics for the board and waivers to the ethics code & 0 & 1 \\
\hline
\end{tabular}

(TO BE CONTINUED) 
(CONTINUATION)

\begin{tabular}{|c|c|c|c|}
\hline 30 & A code of ethics for all company employees & 1 & 1 \\
\hline 31 & Policy on "whistle blower" protection for all employees & 0 & 1 \\
\hline 32 & Mechanisms protecting the rights of other stakeholders in business & 0 & 1 \\
\hline 33 & The role of employees in corporate governance & 0 & 1 \\
\hline \multicolumn{2}{|r|}{ Board and management structure and process (category) } & 9 & 18 \\
\hline 34 & $\begin{array}{l}\text { Governance structures, such as committees and other mechanisms to } \\
\text { prevent conflict of interest }\end{array}$ & 1 & 1 \\
\hline 35 & "Checks and balances" mechanisms & 0 & 1 \\
\hline 36 & Composition of board of directors (executives and non-executives) & 1 & 1 \\
\hline 37 & Composition and function of governance committee structures & 1 & 1 \\
\hline 38 & Role and functions of the board of directors & 1 & 1 \\
\hline 39 & Risk management objectives, system and activities & 1 & 1 \\
\hline 40 & Qualifications and biographical information in the board members & 1 & 1 \\
\hline 41 & Types and duties of outside board and management positions & 0 & 1 \\
\hline 42 & Material interests of members of the board and management & 0 & 1 \\
\hline 43 & Existence of plan of succession & 0 & 1 \\
\hline 44 & Duration of director's contracts & 1 & 1 \\
\hline 45 & $\begin{array}{l}\text { Compensation policy for senior executives departing the firm as a result } \\
\text { of a merger or acquisition }\end{array}$ & 0 & 1 \\
\hline 46 & Determination and composition of directors`remuneration & 1 & 1 \\
\hline 47 & Independence of the board of directors & 0 & 1 \\
\hline 48 & $\begin{array}{l}\text { Number of outside board and management position directorships held by } \\
\text { the directors }\end{array}$ & 0 & 1 \\
\hline 49 & $\begin{array}{l}\text { Existence of procedure(s) for addressing conflicts of interest among } \\
\text { board members }\end{array}$ & 1 & 1 \\
\hline 50 & Professional development and training activities & 0 & 1 \\
\hline 51 & Availability and use of advisorship facility during reporting period & 0 & 1 \\
\hline \multirow[t]{2}{*}{52} & Performance evaluation process & 1 & 1 \\
\hline & TOTAL & 31 & 52 \\
\hline
\end{tabular}

Source: Authors.

Data were collected from annual reports, financial statements, standard financial statements, management reports, notes, sustainability reports, social reports, codes of ethics, codes of conduct, statutes, rules, minutes of council meetings, minutes of board meetings, minutes of other kinds of meeting, notices of meeting, Brazilian Reference Form and 20-F Form. These are all provided by companies on their websites, as well as in information submitted to CVM and BM\&FBovespa, available on these institutions' websites. Data analyzed in this paper were retrieved from documents covering the year 2012.
A data collection instrument was designed using terminology and concepts (key words) extracted from the UN's Guidance on Good Practices in Corporate Governance Disclosure. So, this data collection instrument and the key words were used to identify each firm's practices of CG that were disclosed and are compatible with those recommended by UNCTAD. In each case, the company was assigned the value 1 (one) if the information had been disclosed and 0 (zero) if not. The summary sheets were sent by email to the investor relations department of each firm for review, 
comments and suggestions. Answers and comments of 10 firms were used. After this, all the data were consolidated.

\section{RESULTS AND DISCUSSION}

The analysis parameter was the total of 52 indicators recommended by UNCTAD. The maximum of indicators required by Brazilian rules for disclosure is 31. It was chosen to work with the difference in number between those actually disclosed by companies and two totals: a) that of indicators required by national regulations (31); and b) that of indicators recommended by UNCTAD's beyond the nationally required ones (21, i.e. 52 minus 31). That strategy was considered more relevant to explain the phenomena than working only with disclosed indicators. Thus, under these procedures, it was analyzed which kind of pressure on Brazilian companies is more effective for having them disclose CG.

So, initially, the number of indicators disclosed by each company was computed and two metrical variables were created: Required Indicators Disclosed and Recommended Indicators Disclosed (Table 2, columns 3 and 4). After this, two differences observed for each company were computed: a) between the maximum of required indicators (31) and the ones disclosed, listed in Table 2, column 3; and b) between the maximum of recommended indicators beyond the required ones (21) and the ones disclosed, listed in Table 2, column 4. Both differences correspond respectively to two other metrical variables: Required Indicators Not Disclosed and Recommended Indicators Not Disclosed (see Table 2, columns 5 and $6)$.

Table 2 - Indicators required and recommended disclosed and not disclosed

\begin{tabular}{llcccc} 
No. Company & $\begin{array}{l}\text { Required } \\
\text { Indicators } \\
\text { Disclosed }\end{array}$ & $\begin{array}{c}\text { Recommended } \\
\text { Indicators } \\
\text { Disclosed }\end{array}$ & $\begin{array}{c}\text { Required Indicators } \\
\text { Not Disclosed }\end{array}$ & $\begin{array}{l}\text { Recommended } \\
\text { Indicators Not } \\
\text { Disclosed }\end{array}$ \\
\hline 1 & All amer & 28 & 9 & 3 & 12 \\
2 & AMBEV & 30 & 10 & 1 & 11 \\
3 & B2W & 30 & 13 & 1 & 8 \\
4 & Banco do Brasil & 31 & 16 & 0 & 8 \\
5 & BM\&FBOVESPA & 30 & 13 & 1 & 14 \\
6 & BR MALLS PAR & 26 & 7 & 5 & 2 \\
7 & Bradesco & 31 & 19 & 0 & 12 \\
8 & Bradespar & 28 & 9 & 3 & 8 \\
9 & Braskem & 29 & 11 & 2 & 6 \\
10 & BRF Foods & 30 & 13 & 1 & 18 \\
11 & Brookfield & 29 & 15 & 2 & 7 \\
12 & CCR & 30 & 3 & 1 & 14 \\
13 & CEMIG & 30 & 10 & 0 & 1 \\
14 & CESP & 31 & 15 & 3 & \\
15 & Cetip & 28 & 14 & 2 & \\
16 & Cia Hering & 29 & 7 & & \\
\end{tabular}

(TO BE CONTINUED) 


\section{(CONTINUATION)}

17 Cielo

18 COPEL

COSAN

CPFL Energia

CSN

Cyrella

Dasa

Duratex

ELETROPAULO

ELETROBRAS

Embraer

Energias BR

Fibria

Gafisa

Gerdau

Gol

Hypermarcas

ITAÚ S.A.

ItaúUnibanco

JBS

Kablin S.A.

LIGHT

LLX Log

Localiza

41 LojasAmericanas

Marfrig

Metalúrgica Gerdau

MMX Miner

Mrv

Natura

OGX Petróleo

Oi

Pão de Açúcar

PDG Realt

Petrobras

Renner

Rossi Resid

Sabesp

Santander

Sousa Cruz

57 Suzano

58 TelefComunicações

59 TIM

60 Trans Paulist

61 Ultrapar

62 Usiminas

63 V-agro

64 Vale

Source: Authors.

The Kolmogorov-Smirnov test was

run, as Table 3 shows, to choose between a
13

14

16

10

12

11

12

11

11

12

15

11

15

10

14

12

12

11

10

12

13

13

9

15

10

11

11

11

14

8

13

11

13

10

13

17

10

10

12

9

13

6

15

10

18

10

15

12
7

5

11

10

9

10

10

9

6

10

6

11

7

9

9

10

11

9

8

8

12

6

11

10

10

10

7

13

8

10

8

11

8

4

11

11

9

12

8

15

6

11

3

11

6

9 
Table 3 - Kolmogorov-Smirnov test

Required Indicators Not Disclosed

\begin{tabular}{lll}
\hline Statistic & df & Sig. \\
\hline 0,139 & 64 & 0,004 \\
0,113 & 64 & 0,042
\end{tabular}

Recommended Indicators Not Disclosed

Source: Authors.

Since the level of significance turned out to be below $0,05(5 \%)$ in each variable, the hypothesis of data normality was rejected and a non-parametric test was used (FIELD, 2013). The Wilcoxon signed-rank test was important to check whether there was a significant difference between the medians of the two variables. So, a descriptive analysis of these was computed to check the medians, as Table 4 shows.

Table 4 - Descriptive analysis

\begin{tabular}{ll}
\hline & Median \\
\hline Required Indicators Not Disclosed & 3 \\
Recommended Indicators Not & 9 \\
Disclosed &
\end{tabular}

Source: Authors.

Given a difference between these two medians, a Wilcoxon signed-rank test was carried out, as presented in Table 5.

Table 5 - Wilcoxon signed-rank test

\begin{tabular}{|c|c|c|c|c|}
\hline Null Hypothesis & Test & Sig. & Decision & \\
\hline The median of difference & Related-samples & 0,000 & Reject the & null \\
\hline Required & Wilcoxon Signed-Rank & & hypothesis. & \\
\hline Indicators Not Disclosed & Test & & & \\
\hline Recommended & & & & \\
\hline $\begin{array}{l}\text { Indicators Not Disclosed } \\
\text { equals } 0\end{array}$ & & & & \\
\hline
\end{tabular}

Source: Authors.

Because a significant difference exists between the medians of the two variables (Required Indicators Not Disclosed and Recommended Indicators Not Disclosed), it was explored in depth what had possibly happened to each category previously identified in the
UNCTAD framework. In light of that, three quantities of indicators were considered: the total recommended by UNCTAD, the subtotal of this required by national regulations and, finally, the difference between both those numbers, as presented in Table 6 , organized by category.

Table 6 - Total of indicators recommended by UNCTAD, required by national regulations and recommended beyond those required

\begin{tabular}{llll}
\hline Category & $\begin{array}{l}\text { Total } \\
\text { Recommended by } \\
\text { UNCTAD }\end{array}$ & $\begin{array}{l}\text { Total Required by } \\
\text { National } \\
\text { Regulation }\end{array}$ & $\begin{array}{l}\text { Recommended } \\
\text { beyond } \\
\text { required } \\
\text { those }\end{array}$ \\
\hline Ownership Structure and Exercise of Control Rights & 9 & 8 & 1 \\
Financial Transparency & 8 & 8 & 0 \\
Auditing & 9 & 4 & 5 \\
Corporate Responsibility and Compliance & 7 & 1 & 6 \\
Board and Management Structure and Process & 19 & 10 & 9 \\
Total & 52 & 31 & 21 \\
\hline
\end{tabular}

Source: Authors. 
After this, the numbers in columns 3 and 4 of Table 6 were compared to the total of indicators disclosed by each company analysed. All the data were consolidated so as to calculate the difference medians, organized by category in two new tables. Table 7 is about the difference between the companies' number of indicators disclosed and the required maximum displayed in Table 6 column 3 .

Table 7 - Median for each category of the number of indicators required not disclosed

\begin{tabular}{|c|c|c|c|c|c|}
\hline & $\begin{array}{l}\text { Ownership } \\
\text { Structure and } \\
\text { Exercise of } \\
\text { Control Rights }\end{array}$ & $\begin{array}{l}\text { Financial } \\
\text { Transparency }\end{array}$ & Auditing & $\begin{array}{l}\text { Corporate } \\
\text { Responsibility } \\
\text { and Compliance }\end{array}$ & $\begin{array}{ll}\text { Board } & \text { and } \\
\text { Management } & \\
\text { Structure and } & \\
\text { Process } & \end{array}$ \\
\hline Median & 1,00 & 0,00 & 0,00 & 0,00 & 0,00 \\
\hline
\end{tabular}

Source: Authors.

As for Table 8, with data also organized by category, it displays the medians related to the difference between the companies' number of indicators disclosed and the numbers shown in Table 6, column 4: recommended indicators beyond the required ones.

Table 8 - Median for each category of the number of indicators recommended beyond those required and not disclosed

\begin{tabular}{|c|c|c|c|c|c|}
\hline & $\begin{array}{l}\text { Ownership } \\
\text { Structure and } \\
\text { Exercise of } \\
\text { Control } \\
\text { Rights } \\
\end{array}$ & $\begin{array}{l}\text { Financial } \\
\text { Transparency }\end{array}$ & Auditing & $\begin{array}{l}\text { Corporate } \\
\text { Responsibility } \\
\text { and Compliance }\end{array}$ & $\begin{array}{l}\text { Board } \\
\text { Management } \\
\text { Structure and } \\
\text { Process }\end{array}$ \\
\hline Median & 0,00 & 0,00 & 2,00 & 1,00 & 5,00 \\
\hline
\end{tabular}

Source: Authors.

According to Table 7, a difference was observed between the Ownership Structure and Exercise of Control Rights category $(1,00)$ and the others. Consequently, the Wilcoxon signed test was run between that and the other categories. According to Table 8, both the Ownership Structure and Exercise of Control Rights category and the Financial Transparency category $(0,00)$ showed a difference with respect to the others. Therefore, a Wilcoxon signed test was also carried out. As presented in Table 4, a significant difference was noticed between the medians of Required and Recommended Indicators Not Disclosed: 3 for the former and 9 for the latter. It means that the studied Brazilian companies disclosed more required indicators than those only recommended by UNCTAD.

This finding is not in accordance with Lattemann (2014), who argued that firms from BRIC countries adopt international best practices about corporate governance information beyond those required by national corporate governance codes. However, he admits that "only a small number of 13 corporate governance 
best practices and a small number of countries have been selected and coded for this analysis. The presented results have to be interpreted with some caution" (LATTEMANN, 2014, p. 329). It follows that our study has a wider amplitude -52 corporate governance best practices instead of only 13 -, another difference being our focus on only one country.

Our result confirms the hypothesis previously raised by literature review. In fact, the Brazilian companies listed in BM\&FBovespa are stimulated to comply with national regulation or justify why they do not disclose the required indicators, which suggests they would tend to disclose this information less if they were not urged to, as argued Aguilera and Cuervo-Cazurra (2004). In Brazil, the liberal market prevails and influences a higher CG disclosure as pointed out by Aguilera and Jackson (2003). Moreover, the required compliance with law encourages the Brazilian companies listed in BM\&FBovespa to disclose more in order to avoid penalties and other sanctions, as asserts Gilson (2000). Accordingly, it is convenient to add that, just as Proimos (2005) pointed out, regulation needs to strengthen corporate governance principles and to monitor companies with more stringent penalties. Bhasa (2004) argued that it is a big challenge to make national
$\mathrm{CG}$ practices meet international recommendations and that political impetus is important to this transition.

The results are according to Samaha et al. (2012), a study on Egyptian companies, which tend to disclose more required indicators than those recommended by UNCTAD. There is also resonance with the study published by UNCTAD (2007), related to 25 developing countries in which the Brazilian companies studied disclosed most practices recommended by UNCTAD. Moreover, Oliveira (2013) shows the Brazilian companies studied by her disclosed more than three quarters as much as UNCTAD's recommended indicators.

A further important result about required indicators not disclosed, as noted in Table 7 and confirmed with Wilcoxon signed test is that there is a significant difference, $5 \%$, only between the medians of two categories: the Ownership Structure and Exercise of Control Rights $(1,00)$ and the Corporate Responsibility and Compliance $(0,00)$. That means that the studied Brazilian companies tend to disclose more indicators required belonging to Corporate Responsibility and Compliance than those in Ownership Structure and Exercise of Control Rights category. 
Thus, although those companies do not disclose all the indicators required, there is a difference between the two categories. With respect to the former, as argued Silveira, Leal, Carvalhal-da-Silva and Barros (2010), there is no clear evidence that the ownership structure influences the quality of corporate governance because such a structure can be regarded as a mechanism, regardless of which Collett and Dedman (2010) and Parsa, Chong and Isimoya (2007) pointed out that the higher the level of CEO and board ownership, the lower the level of disclosure.

As for the other category, the corporate responsibility in Brazil is an important driver to collect funds for investments from financial institutions because these are co-responsible for the investments made by their clients. This is confirmed by Alon, Lattemann, Fetscherin, $\mathrm{Li}$ and Schneider (2010) insofar as they assert that Brazil is more concerned with the protection of environment than other countries belonging to the BRIC block. Additionally, it is reasonable for companies to disclose more information about this category, even if it includes only one required indicator: "A code of ethics for all company employees". When compared to the first category, Corporate Responsibility and Compliance contains 8 indicators among 9 whose disclosure of information is required.

Besides, as displayed in Table 8 and confirmed with the Wilcoxon signed test, the medians of recommended indicators not disclosed of all the categories is significant at $5 \%$. Thus, the listed Brazilian companies tend to disclose more recommended indicators that belong to Ownership Structure Exercise of Control Rights and Financial Transparency than those of other categories. Furthermore, the same companies tend to disclose fewer recommended indicators belonging to the Board Management Structure and Process category than indicators of other categories.

This finding partially meets the study carried out in Singapore by Eng and Mak (2003) and by Akhtaruddin and Haron (2010) in Malaysia. In Brazil, the companies follow either private or governmental ownership and sometimes a mix of these. The companies with governmental ownership listed in BM\&FBovespa tend to disclose more information about their ownership voluntarily.

Moreover, the Brazilian companies listed tend to voluntarily disclose their corporate governance information in general, in order to show investors and other stakeholders more transparency. This 
strengthens the previously mentioned finding about the disclosure on Corporate Responsibility and Compliance required indicators as well as it coincides with Ho et al. (HO; SHUN WONG, 2001), a research on companies listed in Honk Kong Stock Exchange, and with Collet and Hrasky (COLLETT; HRASKY, 2005), a study related to companies listed in Australian Stock Exchange.

\section{CONCLUSION}

It follows from all the discussion that coercive forces exert on the Brazilian companies studied more influence in favor of disclosing corporate governance because a significant difference was observed between the medians of Required (3) and Recommended Indicators Not Disclosed (9). This result confirms the hypothesis, implying that the studied Brazilian companies disclosed more required indicators than those only recommended by UNCTAD.

It also highlights the important role of institutions able to impose sanctions, fines and penalties related to $\mathrm{CG}$ disclosure in countries like Brazil, whose law code system prevails. Institutions like Securities and Exchange Commissions and Stock Exchanges as well as laws that have recently been upgraded and inserted new requirements related to disclosure of corporate governance information, had an important contribution to reinforcing the transparency of disclosure.

Even if some countries, aiming to avoid excessive regulation, believe disclosure of information could be voluntary or simply recommended, the results here are in accordance with other studies presented in literature review, which found companies not to actually disclose information voluntarily because it is strategic not to show the risk involved both in decisions approved by the boards and in audits.

In Brazilian leading companies, the disclosure of information not required by regulations related to the Board and Management Structure and Process and Auditing were less disclosed than those related to the Corporate Responsibility and Compliance, even if these are mainly not required either. This result can be explained by the fact that there is the recommendation by the Brazilian Stock Exchange to disclose or justify why not to disclose the sustainability report.

Hence, no regulation or no pressure on corporate responsibility, even if by a recommendation, results in no disclosure or hardly any. This highlights the importance of institutional coercive forces contributing to disclosure. Finally, it is 
relevant to mention that even the required information was not completely disclosed by Brazilian leading companies belonging to IBOV.

The results cannot be applied to all Brazilian companies because the sample is not probabilistic but intentional. So, it is suggested to apply the methodology developed in this study to a more representative population in future research. Furthermore, concerning the Auditing category and the Board and Management Structure and Process category, the Recommended Indicators Not
Disclosed variable for each company of the new sample should probably be contrasted with the existence of an auditing committee and external board members, aiming to verify whether or not there is pressure to disclose the indicators of those categories. This could demonstrate the influence of normative pressure arising from institutional standards of auditing and boards.

\section{ACKNOWLEDGEMENT}

The authors thank the Conselho Nacional de Desenvolvimento Científico e Tecnológico (CNPq) for its sponsorship. 


\section{REFERENCES}

AGUILERA, R. V; CUERVO-CAZURRA, A. Codes of Good Governance Worldwide: What is the Trigger? Organization Studies, v. 25, n. 3, pp. 415-443, 2004.

AGUILERA, R. V.; JACKSON, G. The Cross-National Diversity of Corporate Governance Dimensions and Determinants. Academy of Management Review, v. 26, n. 3, pp. 447-465, 2003.

AKHTARUDDIN, M.; HARON, H. Board ownership, audit committees' effectiveness, and corporate voluntary disclosures. Asian Review of Accounting, v. 18, n. 3, pp. 245-259, 2010.

ALON, I.; LATTEMANN, C.; FETSCHERIN, M.; LI, S.; SCHNEIDER, A.-M. Usage of public corporate communications of social responsibility in Brazil, Russia, India and China (BRIC). International Journal of Emerging Markets, v. 5, n. 1, pp. 6-22, 2010.

BARAKO, D. G.; HANCOCK, P.; IZAN, H. Y. Relationship between corporate governance attributes and volutanry disclosures in annual reports: the Kenyan Experience. Financial Reporting, Regulation and Governance, v. 5, n. 1, 2006.

BHASA, M. P. Global corporate governance: debates and challenges. Corporate Governance, v. 4, n. 2, pp. 5-17, 2004.

BRASIL. Instrução CVM No 480 com as Alterações Introduzidas pelas Instruções CVM N ${ }^{\circ}$ 488/10, 509/11, 511/11, 520/12, 525/12 E 547/14, CVM - Comissão de Valores Mobiliários, 7 Dezembro de 2009, pp. 1-96.

CHENG, E. C. M.; COURTENAY, S. M. Board composition, regulatory regime and voluntary disclosure. The International Journal of Accounting, v. 41, n. 3, pp. 262-289, 2006.

COASE, R. H. The Nature of the Firm. Economica, v. 4, n. 16, pp. 386-405, 1937.

COLLETT, N.; DEDMAN, E. Large share price movements, the disclosure of news and corporate governance. Journal of Applied Accounting Research, v. 11, n. 2, pp. 109-132, 2010 .

COLLETT, P.; HRASKY, S. Voluntary Disclosure of CG practices by Listed Australian 
Companies. Corporate Governance, v. 13, n. 2, pp. 188-196, 2005.

DIAMOND, D. W.; VERRECCHIA, R. E. Disclosure, Liquidity, and the Cost of Capital. The Journal of Finance, v. 46, n. 4, 1991.

ENG, L. L.; MAK, Y. T. Corporate governance and voluntary disclosure. Journal of Accounting and Public Policy, v. 22, n. 4, pp. 325-345, 2003.

FIELD, A. Discovering Statistic Using IBM SPSS Statistics, 4. ed., London, Sage Publications Ltd, 2013.

GILSON, R. J. Transparency, Corporate Governance and Capital Markets. The Latin American corporate governance Roundtable, OECD, São Paulo, 2000.

HO, S. S.; WONG, K. S. A study of the relationship between corporate governance structures and the extent of voluntary disclosure. Journal of International Accounting, Auditing and Taxation, v. 10, n. 2, pp. 139-156, 2001.

JENSEN, M. C.; MECKLING, W. H. Theory of the Firm: Managerial Behavior, Agency Costs and Owership Structure. Journal of Financial Economics, v. 3, n. 4, pp. 305-360, 1976.

LATTEMANN, C. On the convergence of CG practices in emerging markets. International Journal of Emerging Markets, v. 9, n. 2, pp. 316-332, 2014.

OECD. OECD Principles of Corporate Governance 2004, Paris, 2004.

OLIVEIRA, M. C. Review of the Implementation Status of Corporate Governance Disclosures: Brazil. Geneva: United Nations, 2013.

PARSA, S.; CHONG, G.; ISIMOYA, E. Disclosure of governance information by small and medium-sized companies. Corporate Governance: The international journal of business in society, v. 7, n. 5, pp. 635-648, 2007.

PROIMOS, A. Strengthening corporate governance regulations. Journal of Investment Compliance, v. 6, n. 4, pp. 75-84, 2005.

SAMAHA, K.; DAHAWY, K., HUSSAINEY, K., STAPLETON, P. The extent of corporate 
governance disclosure and its determinants in a developing market: The case of Egypt. Advances in Accounting, v. 28, n. 1, pp. 168-178, 2012.

SCOTT, W. R. Institutions and Organizations, Thousand Oaks, CA, Sage Publications, 1995.

SILVEIRA, A. D. M.; LEAL, R. P. C.; CARVALHAL-DA-SILVA, A. L.; BARROS, L. A. B. de C. Endogeneity of Brazilian corporate governance quality determinants. corporate governance, v. 10, n. 2, pp. 191-202, 2010.

UNCTAD - United Nations Conference on Trade and Development. Guidance on Good Practices in Corporate Governance Disclosure. Geneva: United Nations, 2006.

2007 Review of the Implementation Status of Corporate

Governance Disclosures: An Inventory of Disclosure Requirements in 25 Emerging Markets. Geneva: United Nations, 2007.

2008 Review of the implementation status of corporate governance disclosures: an examination of reporting practices among large enterprises in 10 emerging markets. Geneva: United Nations, 2008.

2009 Review of the implementation status of corporate governance disclosures: an inventory of disclosure requirements in 24 emerging markets. Geneva: United Nations, 2009.

Geneva: United Nations, 2010.

International Accounting and Reporting Issues 2008 Review.

International Accounting and Reporting Issues 2010 Review.

Geneva: United Nations, 2011a.

corporate governance Disclosure in Emerging Markets.

Geneva: United Nations, 2011b.

UNITED STATES. Sarbanes-Oxley Act., 107th Congress, 2002, pp. 745-810.

VICENTE, E. F. R.; BORBA, J. A.; ALVES, J. L.; SCHARF, L. Adêrencia do relatório da administração das empresas listadas no novo mercado da BM\&FBovespa ao guia de boas 
ANALYSIS OF CORPORATE GOVENANCE DISCLOSURE: A STUDY ON BRAZILIAN COMPANIES

práticas de governança corporativa da UNCTAD. Revista de Contabilidade de Mestrado em Ciências Contábeis da UERJ, v. 12, n. 2, pp. 1-15, 2007. 